pre-trial investigation for their compliance with the system of target criteria; preparation of analytical documents.

Key words: variability of individual characteristics, descriptors, identification, information, information system, contour analysis, correlation, method, pattern recognition.

DOI: $10.33766 / 2524-0323.88 .240-250$

УДК 343.98

А. В. Коваленко,

кандидат юридичних наук, старший викладач кафедри державно-правових дисциплін Луганського державного університету внутрішніх справ імені Е. О. Дідоренка (м. Сєвєродонецьк, Україна) e-mail: new4or@gmail.com iD http://orcid.org/0000-0003-3665-0147

\title{
СИТУАЦІЙНА ОБУМОВЛЕНІСТЬ ЗБИРАННЯ, ДОСЛІДЖЕННЯ ТА ВИКОРИСТАННЯ ДОКАЗІВ У КРИМІНАЛЬНОМУ ПРОВАДЖЕННІ
}

Стаття присвячена обгрунтуванню ситуаційної обумовленості збирання, дослідження та використання доказів у кримінальному провадженні. Автором проаналізовано основні підходи до розуміння терміна «слідча ситуація» та особливості застосування даного поняття як категорії криміналістичної тактики й методики. Розглянуто інші види криміналістично значущих ситуацій у кримінальному провадженні, зокрема ситуації слідчої (розшукової) дії, техніко-криміналістичні ситуації, експертні ситуації тощо. Запропоновано шляхи вдосконалення криміналістичних рекомендацій за рахунок використання науковцями закономірностей ситуаційної обумовленості доказування в кримінальному провадженні. Визначено пріоритетні напрямки дослідження ситуаційної обумовленості доказування в кримінальному провадженні.

Ключові слова: криміналістична ситуалогія, ситуація, слідча ситуація, доказування, криміналістичні рекомендації.

Постановка проблеми. Прийняття будь яких рішень у кримінальному провадженні, у тому числі щодо застосування тих чи інших техніко- та тактикокриміналістичних засобів збирання й дослідження доказів, зазвичай обумовлено обставинами, у яких приймається відповідне рішення. Сукупність таких обставин, зокрема вся інформація про кримінальне правопорушення, котра наявна в слідства на конкретному етапі розслідування, інші внутрішні та зовнішні фактори, що впливають на розслідування, формують конкретну ситуацію в провадженні, яка і визначає модель поведінки слідчого. Наведене дає підстави говорити про ситуаційну обумовленість кримінально-процесуального доказування, загальні закономірності якої потребують наукового дослідження.

Аналіз останніх досліджень i публікацій. Теоретичні основи криміналістичної ситуалогії були розроблені О. Я. Баєвим, Р. С. Бєлкіним, О. М. Васильєвим, Т. С. Волчецькою, І. Ф. Герасімовим, Г. Л. Грановським, (C) Коваленко А. В., 2019 
Г. А. Густовим, Л.Я.Драпкіним, О. Н. Колесніченком, В. О. Коноваловою, М. О.Селівановим та іншими вченими-криміналістами. Окремі аспекти застосування ситуаційного підходу під час розслідування злочинів у своїх роботах досліджували В. І. Алєксєйчук, С. В. Веліканов, В. А. Журавель, І. Л. Ландау, В. О. Образцов, В. Л. Синчук, Р. Л. Степанюк, В. В. Тищенко, В. М. Шевчук, В. Ю. Шепітько, Г. В. Щербакова, М. Г. Щербаковський та ін. При цьому загальні закономірності ситуаційної обумовленості збирання, дослідження та використання доказів у кримінальному провадженні до сьогодні не отримали достатньої уваги вітчизняних науковців, що підтверджує актуальність даної статті.

Формування цілей. Метою статті $є$ обгрунтування ситуаційної обумовленості збирання, дослідження та використання доказів у кримінальному провадженні, а також формування теоретичних підвалин використання здобутків криміналістичної ситуалогії в процесі доказування.

Виклад основного матеріалу. Одним із основних завдань науки криміналістики є розроблення спрямованих на практику рекомендацій із оптимізації всіх етапів досудового розслідування. Відповідні рекомендації технічного, тактичного та методичного характеру виступають орієнтиром для практикуючих правоохоронців у кримінальному провадженні та базою для навчальних дисциплін, що викладаються в закладах вищої освіти.

Прийняття уповноваженими особами рішень у кримінальному провадженні грунтується на врахуванні цілої низки чинників, зокрема ситуації, що склалася в конкретному провадженні на момент прийняття рішення. Через це розробка більшості практично спрямованих криміналістичних рекомендацій сьогодні спирається на здобутки криміналістичної ситуалогії. Виходячи 3 наведеного, дослідження закономірностей ситуаційної обумовленості кримінального процесуального доказування набуває додаткової актуальності.

Незважаючи на жвавий інтерес науковців-криміналістів та їхній багатий досвід дослідження категорії «слідча ситуація», у наукових колах усе ще точаться суперечки як про підходи до розуміння даного поняття, так і про місце названої категорії в системі криміналістики. Панівними сьогодні є широкий та вузький (або інформаційний) погляди на згадане поняття. У широкому розумінні В. Ю. Шепітько характеризує слідчу ситуацію як сукупність усіх умов, що впливають на розслідування і визначають його особливості. Практично більш значущим, на думку науковця, є поняття слідчої ситуації у вузькому розумінні - як характеристики інформаційних даних, які має слідство на конкретному етапі розслідування [1, с. 128].

Не до кінця визначена і належність слідчої ситуації до певного розділу криміналістичної науки. В. Г. Щербакова зазначає, що різні автори відносять цю категорію до слідчої тактики, включають до складу криміналістичної методики чи пов'язують із загальною теорією криміналістики [2, с. 332]. Так Р. С. Бєлкін відносив слідчу ситуацію до ряду понять криміналістичної тактики, які вже в цій якості, як й інші тактико-криміналістичні поняття, реалізуються в криміналістичній методиці [3, с. 71]. На відміну від нього, С. В. Веліканов розглядав слідчу ситуацію як категорію криміналістичної методики, а класифікацію слідчих ситуацій називав одним із основних завдань криміналістичної методики [4, с. 7]. 
Л. Я. Драпкін зауважував, що будь-яким процесуальним, організаційнопідготовчим та іншим практичним діям слідчого, як правило, передує аналіз вихідних даних, уявне відтворення та оцінка конкретної ситуації в кримінальному провадженні з подальшим прийняттям відповідних рішень. При цьому слідчий прагне до обрання оптимальних рішень, які дозволяють найбільш ефективно вирішити завдання розслідування [5, с. 7]. В. М. Шевчук вважає, що слідча ситуація постійно здійснює управлінський вплив на тактичні засоби в кримінальному провадженні. На його думку, правильне оцінювання слідчих ситуацій та обрання на цій основі тактики розслідування є важливими умовами цілеспрямованості слідства, прийняття науково обгрунтованих й оптимальних рішень тактичного, методичного та техніко-криміналістичного характеру. Тому у якості категорії криміналістичної тактики слідча ситуація в першу чергу розглядається як засіб оптимізації процесу розслідування злочинів [6, с. 149].

Науковці розробляють рекомендації тактичного характеру на основі систематизації та типізації ситуацій досудового розслідування та ситуацій тих чи інших слідчих (розшукових) дій. Видається, що для розробки тактичних рекомендацій більш зручним є широкий підхід до розуміння слідчої ситуації, адже в більшості таких рекомендацій, окрім інформаційної складової, автори звертають увагу й на зовнішні по відношенню до слідчого фактори розслідування: доступність техніко-криміналістичних засобів, поведінку інших учасників процесуальних дій, наявність протидії розслідуванню, тактичного ризику тощо.

Використання ситуаційного підходу сьогодні є панівною передумовою розробки методик розслідування окремих видів злочинів. Посилаючись на ретроспективну спрямованість розслідування, Л. Я. Драпкін зазначав, що створення інформаційних моделей реальних слідчих ситуацій є об'єктивною потребою процесу розслідування злочину та однією із закономірностей судового пізнання. Результатом наукового узагальнення істотних ознак, що є спільними для деякої групи конкретних ситуацій, є типові слідчі ситуації, які виступають очевидним прикладом застосування модельно-інформаційного підходу [5, с. 14]. Дійсно, до структури окремих криміналістичних методик науковці в абсолютній більшості випадків включають інформаційні блоки, що присвячені типовим ситуаціям виявлення інформації про кримінальне правопорушення, типовим слідчим ситуаціям початкового етапу розслідування, типовим для визначених ситуацій версіям та орієнтовному алгоритму дій слідчого для вирішення таких ситуацій.

На думку В. А. Журавля, застосування ситуаційного підходу до побудови методик розслідування дозволяє конкретизувати теоретичні та практичні узагальнення, дає можливість використовувати в слідчій діяльності інформацію узагальненого характеру, що є найбільш адекватною для вибору та адаптації типових рішень для подолання складних ситуацій, які виникають у конкретних кримінальних провадженнях [7, с. 203]. Вибір правоохоронцем напряму розслідування злочину обумовлюється результатом аналізу типових слідчих ситуацій, що дозволяє йому правильно оцінити конкретну ситуацію та оптимально спланувати свої дії [8, с. 132]. 
Щодо підстав типізації слідчих ситуацій, то панівною є думка про використання критерію наявності чи відсутності в слідства інформації, що має значення для розслідування [7, с. 195; 9, с. 143]. Наприклад, на думку Р. Л. Степанюка, типізація слідчих ситуацій під час формування методики розслідування злочинів, вчинених у бюджетній сфері України, можлива за умови виділення інформації про окремі елементи найбільш значущих і таких, що часто зустрічаються, компонентів даних про злочин [10, с. 114]. Оскільки типізація ситуацій найчастіше здійснюється на основі інформаційного критерію, можемо стверджувати про пріоритетність вузького розуміння слідчої ситуації для криміналістичної методики.

Таким чином, слідча ситуація, яка склалася на тому чи іншому етапі досудового розслідування, визначає те, як слідчий буде використовувати вже наявні докази та які способи й засоби доказування він обере надалі, який буде обраний перелік та порядок проведення процесуальних дій, які тактичні прийоми будуть використані в процесі їх проведення. Орієнтиром для слідчого можуть служити типові слідчі ситуації розслідування відповідного виду злочину, які були описані науковцями-криміналістами в методиці розслідування такого злочину.

Варто зазначити, що категорія «ситуація» в криміналістиці використовується не тільки щодо слідчих ситуацій. У науковій та енциклопедичній криміналістичній літературі також використовуються поняття експертної ситуації, ситуації слідчої (розшукової) дії (зокрема ситуаціїдопиту, ситуації огляду місця події та ін.), судової ситуації [11, с.739-746], техніко-криміналістичної ситуації, оперативно-розшукової ситуації тощо.

Так В. Ю. Шепітько зазначає, що слідча ситуація й ситуація процесуальної дії не $є$ тотожними поняттями. Слідча (судова) дія характеризується різною кількістю та якістю даних у конкретний момент ії провадження або тією обстановкою дії, що складається в процесі її проведення. Ситуація слідчої (судової) дії має відносну самостійність, обумовлену специфікою та межами процесуальної дії. За обсягом понять ситуація слідчої (судової) дії є ситуацією меншого ступеня спільності порівняно зі слідчою ситуацією. Водночас ситуація процесуальної дії структурно входить до слідчої ситуації і є ї̈ складовою частиною. Ситуація слідчої (судової) дії формується в процесі самої дії і знаходиться в залежності від 1) наявності (одержання) доказового матеріалу або іншої інформації; 2) прогнозу слідчим відповідної тактики й можливості застосування тих чи інших засобів, прийомів і методів; 3) дій суб'єкта, на який звернені тактичні прийоми (їх системи) [1, с. 140].

Зокрема, на думку В. І. Алєксєйчук, тактика огляду місця події передбачає дослідження типових ситуацій, що виникають при його проведенні. Вони визначають особливості пізнавальної діяльності слідчого, зокрема таких їі стадій, як сприйняття, аналіз обстановки місця події, установлення причинних зв'язків, висунення й перевірка слідчих версій. Класифікувати типові ситуації огляду місця події авторка пропонує залежно від (а) характеру й ступеня визначеності місця вчинення злочину, (б) характеру відбиття події, (в) обсягу наявної на момент початку проведення огляду інформації про подію, (г) складності обстановки місця події, ступеня й характеру наявних змін [12, с. 185]. 
Ситуаційну зумовленість, на думку В. І. Алєксєйчук, має також і залучення під час проведення огляду місця події спеціальних знань, що пов'язано з умовами, способом вчинення злочину, способом його приховування тощо [13, с. 82]. У цьому аспекті варто звернути увагу на ще один тип ситуацій, що складаються під час досудового розслідування та мають криміналістичну значущість, - технікокриміналістичні ситуації.

I. Л. Ландау визначає даний вид ситуацій як систему, що склалася в конкретний час та в конкретному місці, при наявності певних матеріальнотехнічних ресурсів та учасників, при правильній оцінщі якої суб'єкт, що має повноваження вирішити ситуацію, може найбільш раціонально та ефективно застосувати криміналістичну техніку. До компонентів такої ситуації авторка відносить слідову картину, час, метеорологічні умови, матеріально-технічні ресурси, суб'єкта та інших учасників процесуальної дії та наполягає на підвищеній ефективності використання техніко-криміналістичних засобів із застосуванням ситуаційного підходу [14, с. 10-11].

Науковцями-криміналістами досліджувалися також і судово-експертні ситуації, які визначаються як обстановка та сукупність об'єктивних й суб'єктивних умов, у яких проходить процес проведення судової експертизи, що включає підготовку матеріалів, провадження дослідження, оцінку висновку експерта. У структурі названих ситуацій М. Г. Щербаковський виділяє вихідні (доекспертні), проміжні (власне експертні) та кінщеві (постекспертні) ситуащії [15, с. 182-184].

Усі етапи кримінального провадження більшою чи меншою мірою пов'язані з доказуванням. Учених-криміналістів у першу чергу цікавлять такі його стадії, як збирання, дослідження та використання доказів. На думку В. А. Журавля, закономірності одержання, дослідження та використання інформації про злочин у доказуванні як складова предмету криміналістики виявляються ситуаційно, залежно від конкретних кримінальних і слідчих ситуацій, індивідуальних властивостей та ознак об'єктів дослідження, неоднозначності форм взаємозв' язків між ними. Науковець припускає наявність зв'язків між такими закономірностями та іменує їх криміналістичним детермінізмом, який полягає в залежності криміналістичних засобів і методів роботи з інформацією про подію злочину від характеру цієї події та породжених нею наслідків [16, с.9]. Встановлення названих закономірностей сьогодні $\epsilon$ одним із основних напрямків наукового пошуку в криміналістиці.

В. Ю. Шепітько вважає, що стосовно типових ситуацій можна намітити певний спосіб дій слідчого в процесі одержання доказової інформації [1, с. 143]. Вважаємо, що дана теза може повною мірою бути застосована до обрання слідчим, спеціалістом, експертом та іншими уповноваженими особами технікота тактико-криміналістичних методів та засобів збирання доказів, а також шляхів їх використання. Це означає, що типізації та науковому аналізу підлягають не лише слідчі, а й інші види криміналістично значущих ситуацій.

Таким чином, протягом усього кримінального провадження складаються ситуації різного рівня та різної складності, які впливають на процес розслідування й судового розгляду та визначають поведінку уповноважених осіб відповідно до їх завдань у провадженні. Такі ситуації пов'язані між собою, у 
тому числі й причинно-наслідковими зв'язками, які полягають у тому, що вирішення однієї з них призводить до формування наступної аж до моменту, коли, із вирішенням останньої, мета відповідного учасника провадження буде досягнута. Задля розробки практично спрямованих криміналістичних рекомендацій щодо кожного з видів ситуації, можливо визначити обставини та умови, що їх формують, підстави їх типізації, а також орієнтовні алгоритми дій для їх вирішення.

3 огляду на викладене, вважаємо за можливе зробити висновок про те, що застосування ситуаційного підходу притаманне використанню всіх основних засобів та способів доказування в кримінальному провадженні. Усі основні операції із доказами є ситуаційно обумовленими, що сьогодні визнається та активно використовується вченими при розробці спрямованих на практику рекомендацій.

Варто зауважити, що криміналістичні рекомендації технічного, тактичного та методичного характеру не можуть бути достатньо ефективними, якщо вони розроблюються та використовуються відокремлено одна від одної. Слідча діяльність, на яку спрямовані згадані рекомендації, на практищі завжди має комплексний характер. Так у кримінальному провадженні технікокриміналістичні засоби використовуються в ході реалізації тактики проведення слідчих (розшукових) дій, орієнтовний перелік та порядок проведення яких, у свою чергу, є предметом дослідження криміналістичної методики. Утім сьогодні в криміналістичній літературі здебільшого розрізнено досліджуються закономірності доказування під час розслідування окремих видів злочинів, під час проведення окремих слідчих (розшукових) дій та в ході використання окремих засобів криміналістичної техніки. Результатами таких досліджень стають методичні, тактичні та технічні криміналістичні рекомендації відповідно.

Подібні розробки можуть узагальнюватися в монографічних працях більш комплексного характеру 3 урахуванням у них загальних закономірностей збирання, дослідження та використання доказів у кримінальному провадженні, зокрема їх ситуаційної обумовленості. Так, наприклад, може бути розроблена міжвидова або родова методика розслідування злочинів, у рамках якої поглиблено досліджено особливості тактики проведення найбільш характерних слідчих (розшукових) дій, особливості техніко-криміналістичного забезпечення розслідування відповідних кримінальних правопорушень. Сучасні ж криміналістичні методики, як правило, надають лише орієнтовні рекомендації тактичного характеру, які, у свою чергу, містять фрагментарну інформацію про особливості застосування засобів криміналістичної техніки під час розслідування окремих видів злочину. У порівнянні 3 цим описана вище модель криміналістичних рекомендацій має білы повно задовольнити потреби практики, зокрема у світлі набираючої оберти тенденції до спеціалізації слідчих. Крім цього, такі комплексні дослідження сприятимуть системності та повноті навчальних матеріалів, які будуть створюватися на їх основі.

I хоча напрямки реформування існуючих підходів до створення криміналістичних рекомендацій є предметом окремого наукового обговорення, можемо зробити висновок, що одним із засобів їх оптимізації є врахування вченими загальних закономірностей використання ситуаційного підходу під 
час збирання, дослідження та використання доказів у кримінальному провадженні. Зокрема такі рекомендації мають грунтуватися на типізації не лише слідчих ситуацій розслідування, а й ситуацій слідчих (розшукових) дій, техніко-криміналістичних ситуацій, експертних ситуацій тощо та пропонувати орієнтовні алгоритми дій для їх вирішення.

Теоретичною базою таких розробок має стати фундаментальне наукове криміналістичне дослідження закономірностей ситуаційної обумовленості збирання, дослідження та використання доказів у кримінальному провадженні, що сформує наукові підвалини використання здобутків криміналістичної ситуалогії в процесі доказування.

Відтак науковий інтерес становлять такі групи криміналістичних закономірностей:

1) ситуаційна обумовленість застосування техніко-криміналістичних способів та засобів збирання й дослідження доказів як закономірності обрання та використання слідчим, спеціалістом чи експертом засобів криміналістичної техніки, які найбільше відповідають ситуації, що склалася;

2) ситуаційна обумовленість використання тактико-криміналістичних способів збирання доказів як закономірності обрання та застосування слідчим тактичних прийомів під час проведення слідчих (розшукових) та негласних слідчих (розшукових) дій залежно від ситуації, що склалася;

3) ситуаційна обумовленість використання доказів у кримінальному провадженні як закономірності оперування слідчим, прокурором, стороною захисту наявними доказами в кримінальному провадженні (в залежності від ситуації розслідування).

Для кожної із груп закономірностей мають бути визначені перелік осіб уповноважених на прийняття рішень, обставини, що впливають на їх прийняття, суттєві складові відповідних ситуацій та підстави їх типізації, а також внутрішні зв'язки між такими закономірностями в кримінальному провадженні. Вважаємо, що для дослідження перелічених вище закономірностей варто виходити із широкого розуміння слідчої ситуації. Грунтовне дослідження ситуаційної обумовленості доказування в кримінальному провадженні дозволить оптимізувати рекомендації щодо прийняття практиками рішень про застосування в типових ситуаціях тих чи інших способів, засобів збирання та дослідження доказів, а також рішень про їх використання в кримінальному провадженні.

Висновки. Підсумовуючи наведене, зазначимо, що застосування ситуаційного підходу є виправданим при використанні всіх основних засобів та способів доказування в кримінальному провадженні. Оскільки алгоритми дій уповноважених осіб у процесі одержання доказової інформації визначаються конкретною ситуацією в провадженні, ситуаційно обумовленим є застосування техніко- й тактико-криміналістичних способів та засобів збирання й дослідження доказів, так само як і використання вже наявних доказів у кримінальному провадженні. Виходячи із цього, ситуаційна обумовленість та закономірності доказування в кримінальному провадженні становлять окремий науковий інтерес і потребують подальшого дослідження. Врахування таких 
закономірностей дозволить оптимізувати розроблювані вченимикриміналістами рекомендації технічного, тактичного та методичного характеру, забезпечити їх актуальність і практичну спрямованість та сприятиме підвищенню якості таких рекомендацій у цілому.

Також зазначимо, що збирання, дослідження та використання доказів у кримінальному провадженні, окрім конкретної ситуації розслідування злочину, обумовлюється й конкретними завданнями, що стоять перед уповноваженою особою в провадженні. Це дає підставу стверджувати й про телеологічну (цільову) обумовленість доказування в кримінальному провадженні, яка має свої закономірності та потребує окремого дослідження.

\section{Використані джерела:}

1. Шепітько В. Ю. Криміналістична тактика (системно-структурний аналіз): Монографія. Харків : Харків юридичний, 2007. 432 с.

2. Щербакова Г. В. Теоретичні засади формування та розвитку криміналістичної ситуалогії. Науковий вісник Дніпропетровського державного університету внутрішніх справ. Дніпропетровськ, 2011. №. 3. С. 331-336.

3. Белкин Р. С. Очерки криминалистической тактики: Учеб. пособие. Волгоград: НИИ МВД РФ, 1993. 200 с.

4. Веліканов С. В. Класифікація слідчих ситуацій у криміналістичній методиці :автореф. дис. ... канд. юрид. наук : 12.00.09. Харків, 2002. 22 с.

5. Драпкин Л. Я. Основы теории следственных ситуаций. Свердловск : Изд-во Урал. ун-та, 1987, 164 с.

6. Шевчук В. М. Слідча ситуація: поняття, структура, види та їх значення для оптимізації розслідування злочинів. Юридичний науковий електронний журнал. 2014. № 1. C. 139-143.

7. Журавель В. А. Криміналістичні методики: сучасні наукові концепції: монографія. Харків : Вид. Агенція «Апостиль», 2012. 304 с.

8. Тіщенко В. В. Теоретичні і практичні основи методики розслідування злочинів : монографія. Одеса : Фенікс, 2007. 260 с.

9. Белкин Р. С. Курс криминалистики: Криминалистические средства, приемы и рекомендации. В 3-х томах. Т. 3. Москва : Юристъ, 1997. 480 с.

10. Степанюк Р. Л. Ситуаційний підхід у формуванні методик розслідування злочинів, вчинених у бюджетній сфері України. Право і безпека. 2013. №. 3. С. 110-115.

11. Велика українська юридична енциклопедія : у 20 т. Т. 20 : Криміналістика, судова експертиза, юридична психологія. Редкол.: В.Ю. Шепітько (голова) та ін. 2018. 952 с.

12. Алєксєйчук В. І. Огляд місця події: тактика і психологія: дис. ... канд. юрид. наук: 12.00.09. Харків, 2007. 240 с.

13. Алєксєйчук В. І. Використання спеціальних знань під час огляду місця події при розслідуванні вбивств. Теорія та практика судової експертизи і криміналістики. 2010. №. 10. С. 79-86.

14. Ландау И. Л. Ситуационный подход в технико-криминалистическом обеспечении предварительного расследования и судебного следствия. Автореф. дис. ...к.ю.н. : 12.00.09. Калининград, 2002. 21 с.

15. Щербаковський, М. Г. Види та сутність судово-експертних ситуацій. Вісник Луганського держаного університету внутрішніх справ ім. Е. О. Дідоренка. 2015. № 3 (71). C. $178-186$. 
16. Журавель. В. А. Предмет криміналістики: генезис та сучасний стан. / Вибрані твори. Харків : Вид. агенція «Апостіль», 2016. С. 5-11.

\section{References:}

1. Shepitko, V. (2007) Kryminalistychna taktyka (systemno-strukturnyi analiz). Kharkiv: Kharkiv yurydychnyi. [in Ukrainian].

2. Shcherbakova, H. (2011) Teoretychni zasady formuvannia ta rozvytku kryminalistychnoi sytualohii. Naukovyi visnyk Dnipropetrovskoho derzhavnoho universytetu vnutrishnikh sprav-Scientific Bulletin of Dnipropetrovsk State University of Internal Affairs. Dnipropetrovsk, 3, 331-336. [in Ukrainian].

3. Belkin, R. (1993) Ocherki kriminalisticheskoy taktiki. Volgograd: NII MVD RF. [in Russian].

4. Velikanov, S. (2002) Klasyfikatsiia slidchykh sytuatsii u kryminalistychnii metodytsi. Extended abstract of candidate's thesis. Kharkiv. [in Ukrainian]. Russian]

5. Drapkin, L. (1987) Osnovyi teorii sledstvennyih situatsiy. Sverdlovsk. [in

6. Shevchuk, V. (2014) Slidcha sytuatsiia: poniattia, struktura, vydy ta yikh znachennia dlia optymizatsii rozsliduvannia zlochyniv. Yurydychnyi naukovyi elektronnyi zhurnal - Legal scientific electronic journal, 1, 139-143. [in Ukrainian].

7. Zhuravel, V. (2012) Kryminalistychni metodyky: suchasni naukovi kontseptsii. Kharkiv: Apostyl. [in Ukrainian].

8. Tishchenko, V. (2007) Teoretychni i praktychni osnovy metodyky rozsliduvannia zlochyniv. Odesa: Feniks. [in Ukrainian].

9. Belkin, R. (1997) (Vols.1-3); Vol.1. Kurs kriminalistiki: Kriminalisticheskie sredstva, priemyi i rekomendatsii. Moskva: Yurist. [in Russian].

10. Stepaniuk R. (2013) Sytuatsiinyi pidkhid u formuvanni metodyk rozsliduvannia zlochyniv, vchynenykh u biudzhetnii sferi Ukrainy. Pravo i bezpeka - Law and security, 3, 110115. [in Ukrainian].

11. Velyka ukrainska yurydychna entsyklopediia (2018) (Vols. 1-20); Vol. 20: Kryminalistyka, sudova ekspertyza, yurydychna psykholohiia. V. Yu. Shepitko (Ed.) et. al. N. p. [in Ukrainian].

12. Alieksieichuk, V. (2007) Ohliad mistsia podii: taktyka i psykholohiia. Candidate's thesis. Khakriv. [in Ukrainian].

13. Alieksieichuk, V. (2010) Vykorystannia spetsialnykh znan pid chas ohliadu mistsia podii pry rozsliduvanni vbyvstv. Teoriia ta praktyka sudovoi ekspertyzy $i$ kryminalistyky - Scientific Bulletin of Dnipropetrovsk State University of Internal Affairs, 10, 7986. [in Ukrainian].

14. Landau, I. (2002) Situatsionnyiy podhod v tehniko-kriminalisticheskom obespechenii predvaritelnogo rassledovaniya i sudebnogo sledstviya. Extended abstract of candidate's thesis. Kaliningrad. [in Russian].

15. Shcherbakovskyi, M. (2015) Vydy ta sutnist sudovo-ekspertnykh sytuatsii. Visnyk Luhanskoho derzhanoho universytetu vnutrishnikh sprav im. E. O. Didorenka - Bulletin of Lugansk State University of Internal Affairs E. O. Didorenko, 3 (71), 178-186. [in Ukrainian].

16. Zhuravel, V. (2016) Predmet kryminalistyky: henezys ta suchasnyi stan. Vybrani tvory. Kharkiv: Apostil, 5-11. [in Ukrainian]. 
Коваленко А. В.,

кандидат юридических наук, старший преподаватель кафедры государственно-правовых дисциплин Луганского государственного университета внутренних дел имени Э. А. Дидоренко (г. Северодонецк, Украина)

\title{
СИТУАЦИОННАЯ ОБУСЛОВЛЕННОСТЬ СБОРА, ИССЛЕДОВАНИЯ И ИСПОЛЬЗОВАНИЯ ДОКАЗАТЕЛЬСТВ В УГОЛОВНОМ ПРОИЗВОДСТВЕ
}

\begin{abstract}
Статья посвящена обоснованию ситуационной обусловленности сбора, исследования и использования доказательств в уголовном производстве. Автором проанализированы основные подходы кпониманию термина «следственная ситуация» и особенности применения данного понятия как категории криминалистической тактики и методики. Рассмотрены другие виды криминалистической значимых ситуаций в уголовном производстве, в частности ситуации следственного (розыскного) действия, технико-криминалистические ситуации, экспертные ситуации и т. д. Предложены пути совершенствования криминалистических рекомендаций за счет использования учеными закономерностей ситуационной обусловленности доказывания в уголовном производстве. Определены приоритетные направления исследования ситуационной обусловленности доказывания в уголовном производстве.

Ключевые слова: криминалистическая ситуалогия, ситуация, следственная ситуация, доказывание, криминалистические рекомендации.

\section{Kovalenko A., Candidate of Law, Senior Lecturer of Department of State-Law disciplines, Luhansk State University of Internal Affairs named after E. O. Didorenko (Sievierodonetsk, Ukraine)}

\section{SITUATIONAL CONDITIONALITY OF COLLECTION, EXAMINATION AND USE OF EVIDENCE IN CRIMINAL PROCEEDINGS}

The purpose of the article is to substantiate the situational conditioning of collection, examination and use of evidence in criminal proceedings. Using the formal-logical method, the situational conditionality of proving in criminal proceedings was established. The system-structural method made it possible to systematize the types of situations in criminal proceedings. Modeling and forecasting methods have become the basis for identifying priority areas for situational conditioning research.

The author analyzes the main approaches to understanding the term "investigative situation" and the peculiarities of applying this concept as a category of forensic tactics and techniques. Other types of forensically significant situations in criminal proceedings are considered, including situations of investigative (search) action, technical and forensic situations, expert situations, etc. The ways of improvement of forensic recommendations at the expense of scientists using regularities of situational conditionality of proving in 
criminal proceedings are offered. Priority directions of investigation of situational conditionality of proving in criminal proceedings are determined.

The use of a situational approach is justified in using all the basic means of proving in criminal proceedings. Since the algorithms of actions of authorized persons in the process of obtaining evidentiary information are determined by the specific situation in the proceedings, the use of technical and tactical-criminalistic methods and means of gathering and examining of evidence, as well as the use of already existing evidence in criminal proceedings, is situationally conditioned. On this basis, the situational conditionality and patterns of evidence in criminal proceedings are of particular scientific interest, and consideration of such regularities will optimize the recommendations of technical, tactical and methodological character developed by the forensic scientists.

Key words: forensic situation, situation, investigative situation, evidence, forensic recommendations.

DOI: 10.33766/2524-0323.88. 250-257

УДК 336.025:347.73

В. Г. Першин,

кандидат юридичних наук,

начальник відділу міжнародних зв' язків

Національної академії прокуратури України

(м. Київ, Україна)

e-mail: pershinv@gmail.com

iDhttps://orcid.org/0000-0002-7562-4964

\section{РОЛЬ ФІНАНСОВОГО МОНІТОРИНГУ В МЕЖАХ ПРОТИДІЇ ЛЕГАЛІЗАЦІЇ ДОХОДІВ, ОДЕРЖАНИХ ЗЛОЧИННИМ ШЛЯХОМ}

У статті розглядається проблематика ролі фінансового моніторингу в межах протидії легалізації доходів, одержаних злочинним шляхом. Зазначається про значне поширення цього негативного явища. Акцентується увага на транснаціональному характері «відмивання» брудних коштів. Пропонуються шляхи удосконалення діяльності системи фінансового моніторингу.

Ключові слова: фінансовий моніторинг, протидія легалізації доходів, «відмивання» грошей, функції публічного управління, злочинність.

Постановка проблеми. Станом на сьогодні Україна потребує суттєвого удосконалення діяльності в царині фінансового моніторингу. Причин такого стану справ достатньо багато. Одна із них полягає в необхідності протидії (легалізації) доходів, одержаних злочинним шляхом. Рівень злочинності, у тому числі й економічної, на жаль, має в Україні тенденцію до зростання. Такі ж невтішні показники й стосовно легалізації (відмивання) доходів, одержаних злочинним шляхом. Значною мірою вказане обумовлене загальним погіршенням криміногенної ситуації в державі та становленням системи фінансового моніторингу в Україні, наявністю низки нерозв'язаних у цьому аспекті проблем. Наразі ми є свідками активного розвитку фінансового законодавства та намагання з боку держави здійснювати реальне запобігання та 